\title{
Comparison of effectiveness of acceptance commitment therapy and metacognitive therapy on reducing symptoms, psychological capital and quality of life of patients suffering from irritable bowel syndrome
}

\author{
Sarah Pashing ${ }^{1}$, Aniss Khosh Lahjeh Sedgh ${ }^{2}$ \\ ${ }^{I}$ Assistant Professor, Faculty of Psychology, Islamic Azad University, Karaj Branch, karaj, Iran \\ ${ }^{2}$ PhD, Health Psychology, Faculty of Psychology, Islamic Azad University, Karaj Branch, karaj, Iran
}

\begin{abstract}
Background: The aim of the present study was to compare effectiveness of metacognitive therapy (MCT) and acceptance commitment therapy (ACT) on reducing syndromes, psychological capital and quality of life of patients suffering from irritable bowel syndrome (IBS).

Materials and methods: Research method was quasi-experimental with pre-test, post- test, three-month follow-up and control group. Statistical population was all 20-40 years old females suffering from IBS who applied to Counseling Center of Pharmaceutical Sciences University located in Tehran City. Through available sampling, 45 patients were selected and assigned randomly in experimental group 1 (MCT), experimental group 2 (ACT) and control group (15 in each group). The Psychological Capital Inventory (Luthans, 1992) and Quality of Life Inventory (Ware \& Sherbourne, 1992) were administered pre-test, posttest and follow-up period. The therapeutic packages of acceptance, commitment therapy and metacognitive therapy applied on experimental groups for eight 90- minute sessions once a week. Control group was placed in a waiting list.

Results: Both therapeutic methods equally increased psychological capital and quality of life in patients suffering from IBS. According to physicians' report and own patients themselves, the symptoms of the disease were significantly reduced. Three- month follow-up confirmed these results.

Conclusion: Since psychosocial factors, in addition to biological elements, influence on severity of IBS symptoms, improving healthy quality of life and psychological capital indicators should be paid attention to prevent and treat this disorder.

Keywords: Acceptance and commitment therapy, Metacognitive therapy, Psychological capital, Quality of life, irritable bowel syndrome.

Cited as: Pashing S, Khosh Lahjeh Sedgh A. Comparison of effectiveness of acceptance commitment therapy and metacognitive therapy on reducing symptoms, psychological capital and quality of life of patients suffering from irritable bowel syndrome. Medical Science Journal of Islamic Azad University, Tehran Medical Branch 2019; 29(2): 181-190.
\end{abstract}

Correspondence to: Sarah Pashing

Tel: +989128937996

E-mail: sarahpashang@yahoo.com

ORCID ID:0000-0001-6609-3260

Received: 24 May 2018; Accepted: 1 Jan 2019 
مجله علوم يزشكى دانشعاه آزاد اسلامى

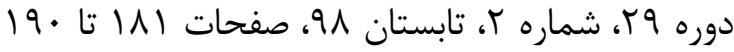

مقايسه اثربخشى درمان مبتنى بر يذيرش و تعهد و درمان فرا شناختى بر كاهش علايم، سرمايه روانشناختى و كيفيت زندگى بيماران مبتلا به سندرم روده

$$
\text { تحريك يذير }
$$

سارا پاشنَ'، انيس خوش لهجه صدق

' استاديار، دانشكده روانشناسى، دانشخاه آزاد اسلامى، واحد كرج، كرج، ايران

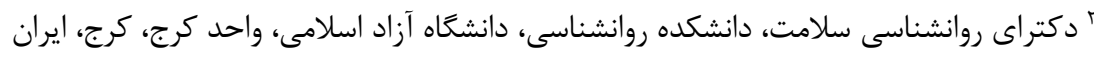

جكيله سابقه و هدف: : يزوهش حاضر با هدف مقايسه اثر بخشى درمانهاى بذيرش و تعهل و فراشناختى بركاهش علايمه سرمايه

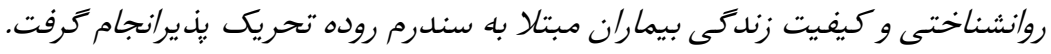

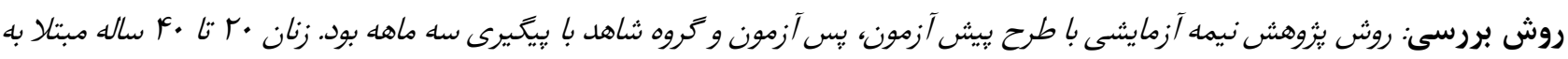

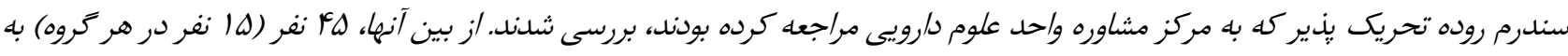

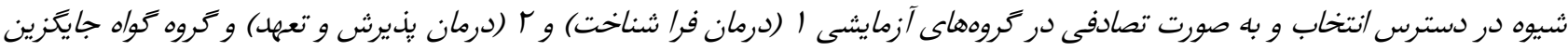

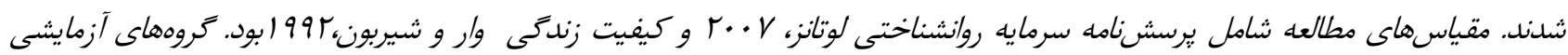

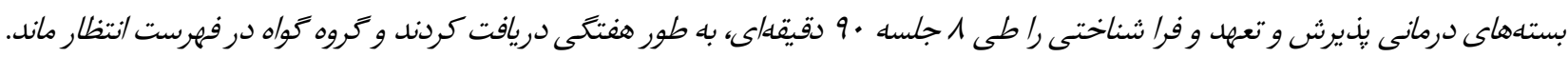

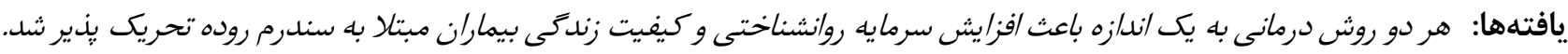

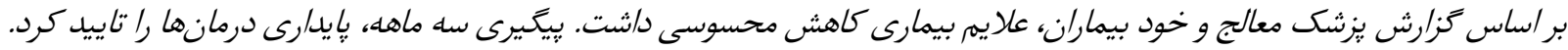

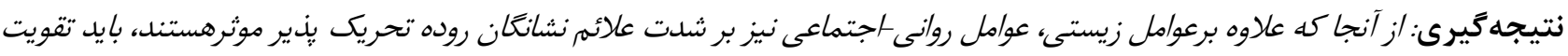

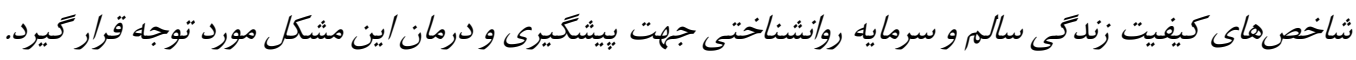

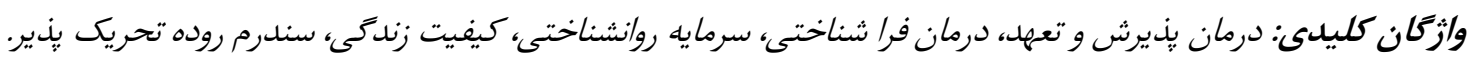

را شامل مىشود كه حدود r ا درصد مردم دنيـا بـه آن مبـتلا

مقدمه

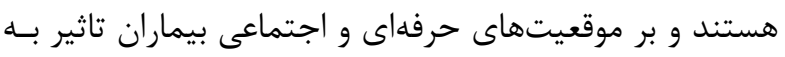

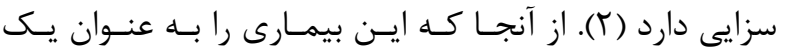

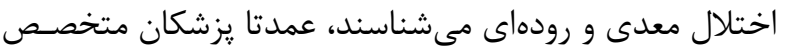

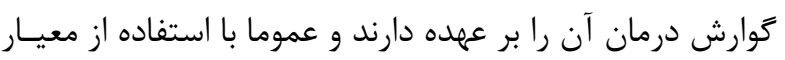

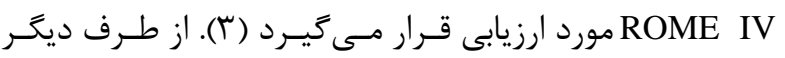
درمان اين اختلال نيز براى تيم تخصصى جالش بزركى اسـت

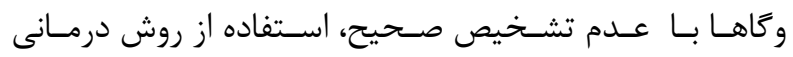

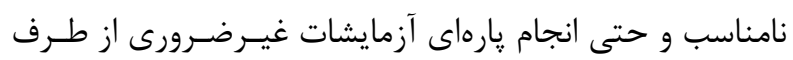

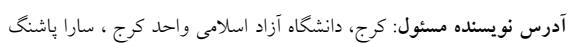
(email: sarahpashang@yahoo.com) ORCID ID:0000-0001-6609-3260: تاريخ دريافت مقاله: 9V/q/r

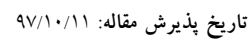


استفاده از جهار جوبهاى درمان يذيرش و تعهد و درمـان فـرا

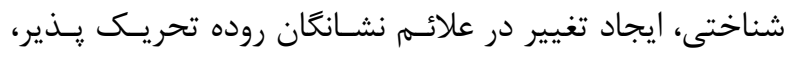

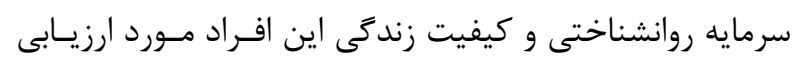

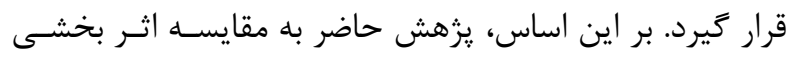

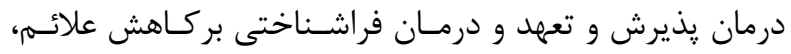

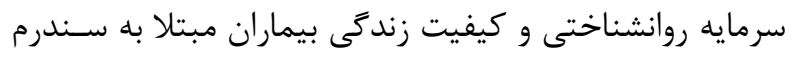
روده تحريك يذير يرداخت.

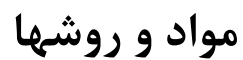

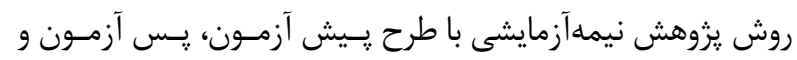

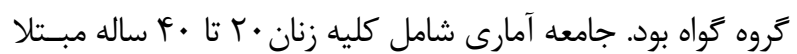

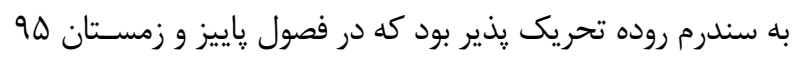

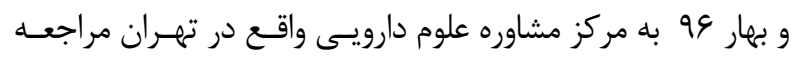

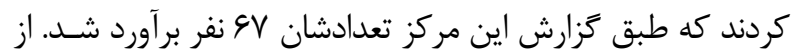

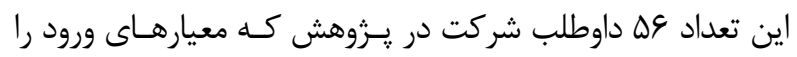

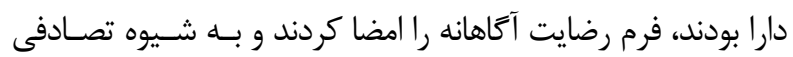

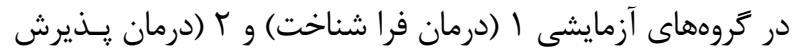

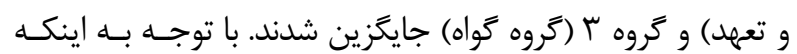

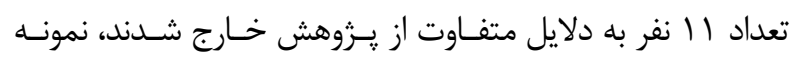

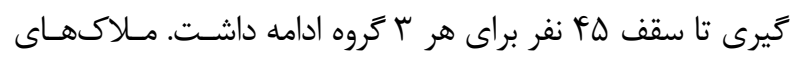

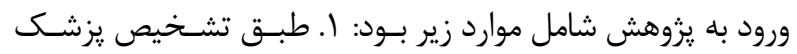

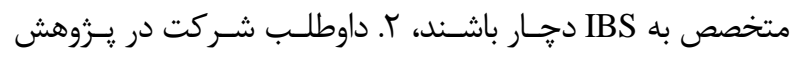

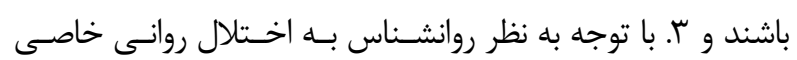

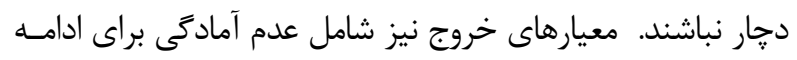

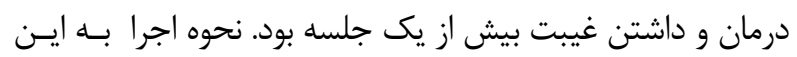

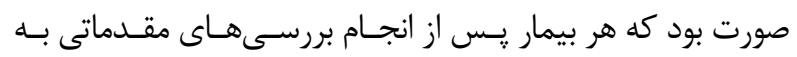

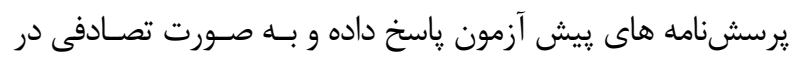

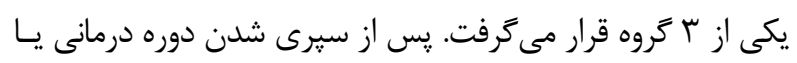

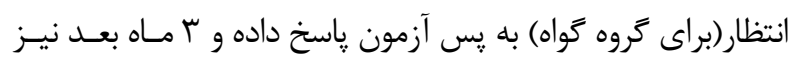

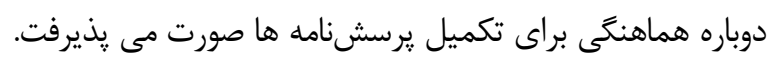

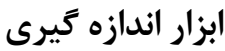

\section{سـرمايه روانشـناختى (PCQ Psychological capital :} (questionnaire

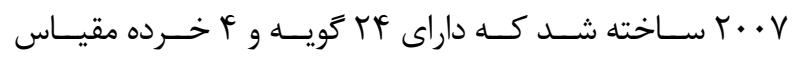

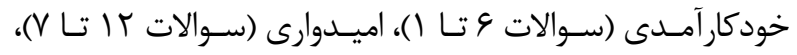

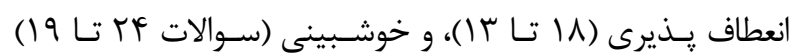

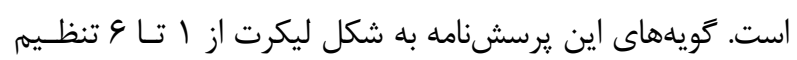

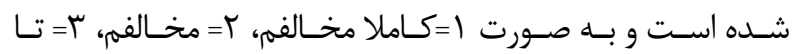

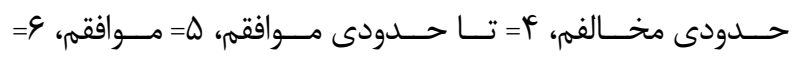

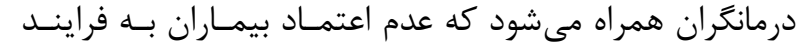

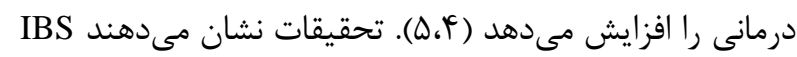
در بين زنان نسبت به مردان شيوع بالاترى دارد. تنها در ايـران

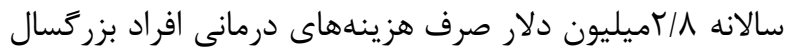

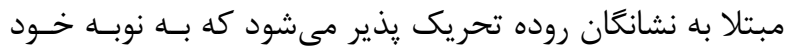

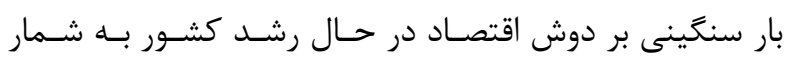

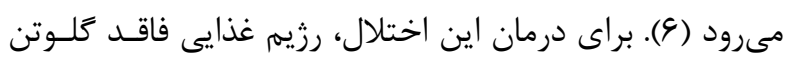

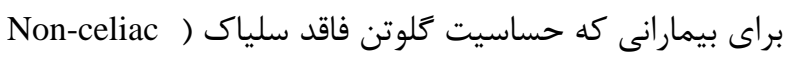
(gluten sensitivity

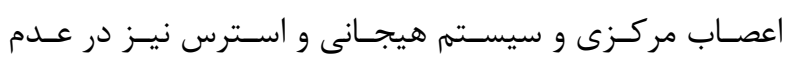

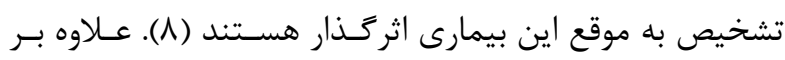

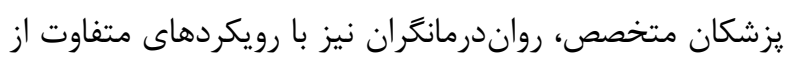

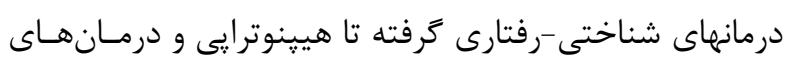

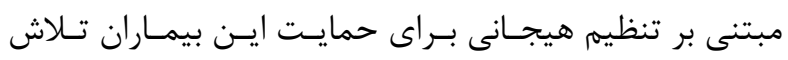

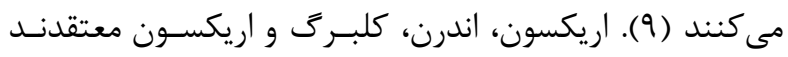

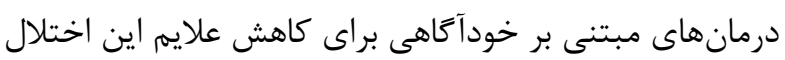

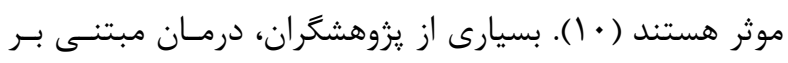

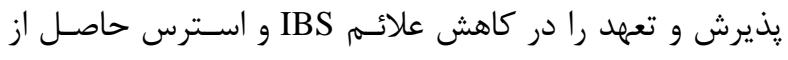

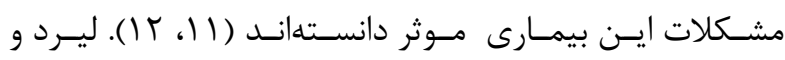

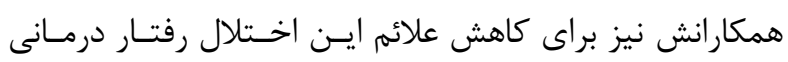

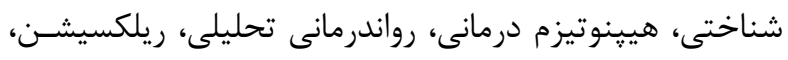

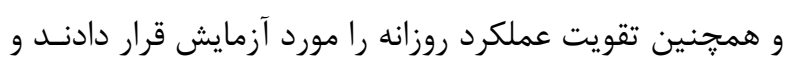

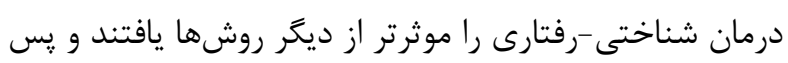

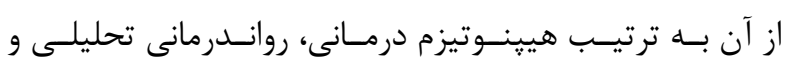

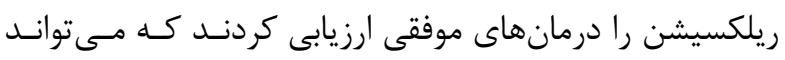

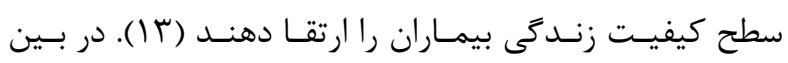

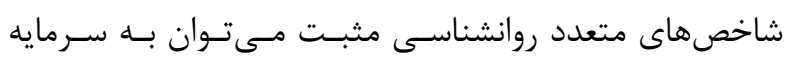

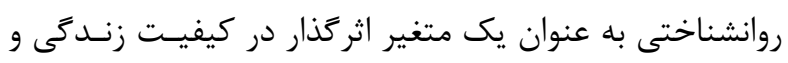

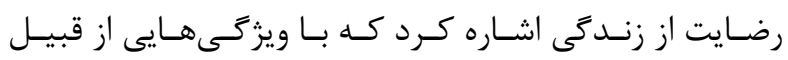

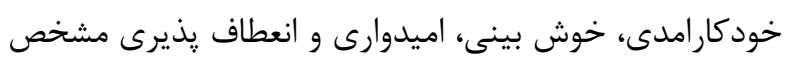

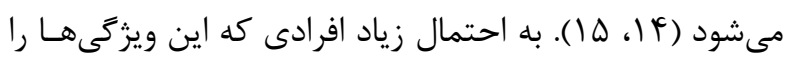

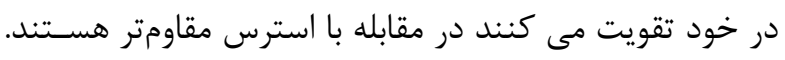

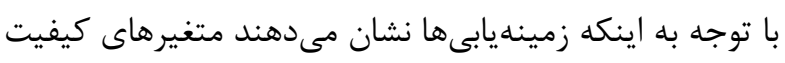

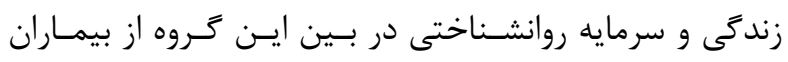

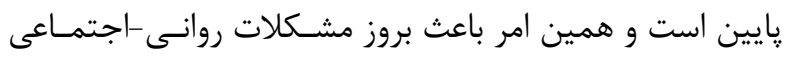

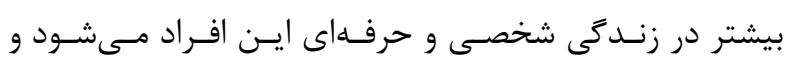

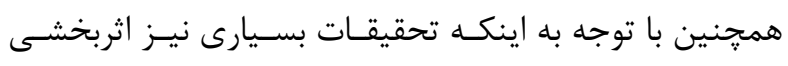

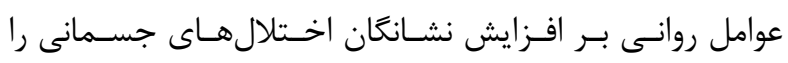

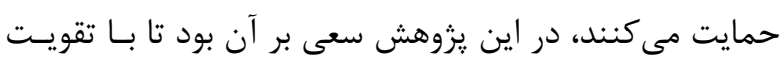

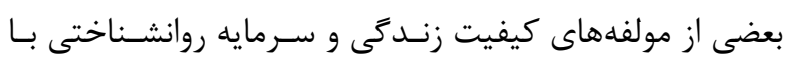




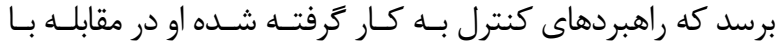

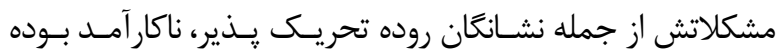

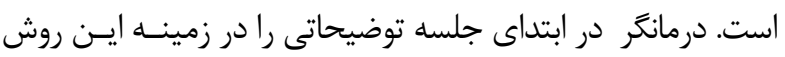
درمانى ارائه داد. همجنين از استعاره ببر كرسنه و اسـتعاره كَّودال و معرفى جهار جوب ذهنى اكر - پِس براى كاهش اضـطراب بيمـار

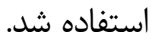
جلسه دوم: در اين مرحله به مراجع نشان داده شـد كـه مشـكلات

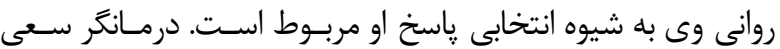

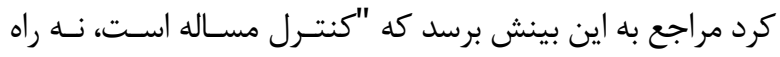

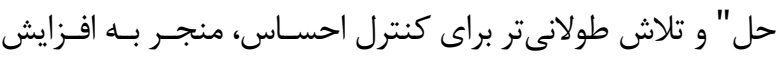

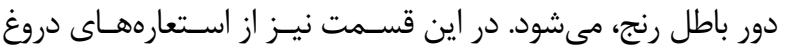
سنجى و باتلاق شنى استفاده شد.

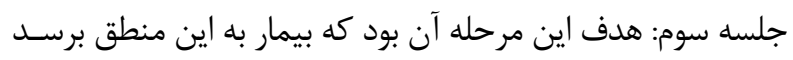

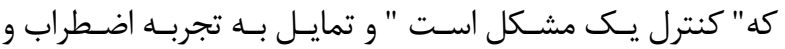
ناراحتى جايكزين كنترل به حساب مسى آينـد. همجنــين درمـانكر

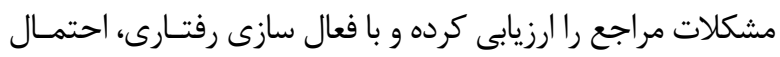

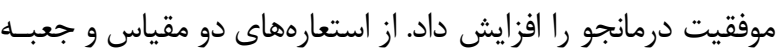
براى سهولت درمان و اموزش بيمار استفاده شد. جلسه جهارم: در اين قسمت مفهوم گسلش از افكـار و احساسـات

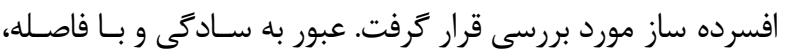

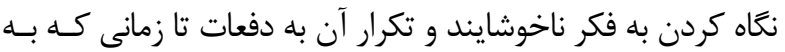

يك صداى بى معنى تبديل شود، آموزش داده شد.

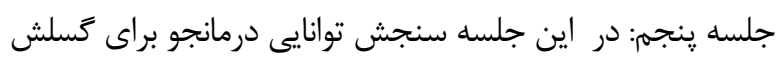

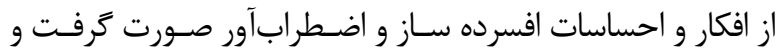

همجنين ساير راه هاى عملى براى يرورش گسلش ارايه شد.

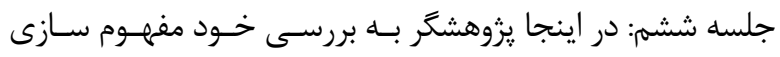

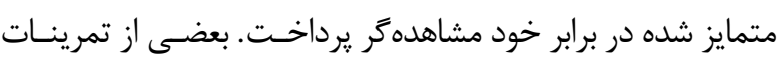
مانند تمرين قطبيت روان، قياس تخته شطرنج، تمرين مشاهدهرك، نيز جهت تسهيل در درمان مورد استفاده قرار كرفت.

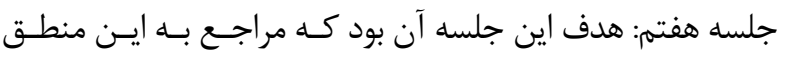

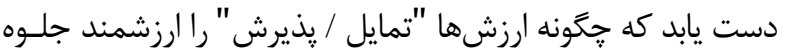

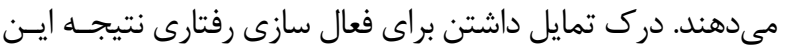
جلسه بود. جهت افزايش انعطاف يذيرى مراجع از مواجهه استفاده

جلسه هشته: در اين مرحله براى شناسايى حوزههايى كه منطبـق

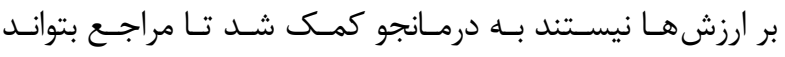

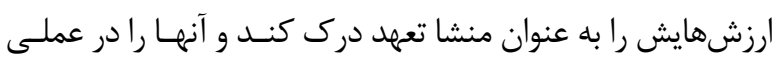

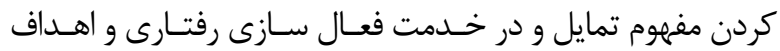
شخصى خود به كار بخيرد. سيس در رابطه با موانع عمل مسئولانه

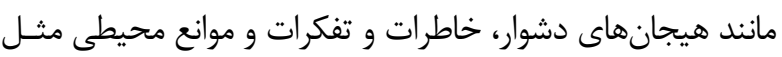

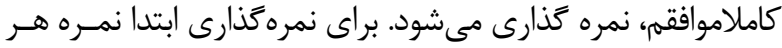

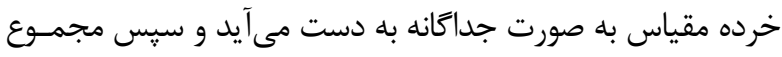

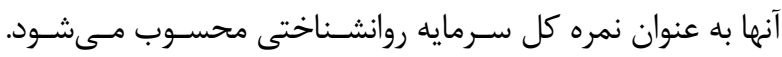

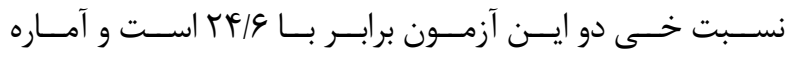

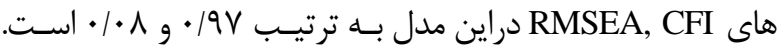

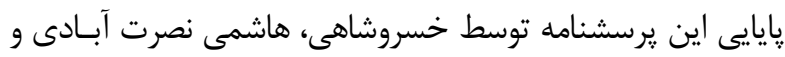

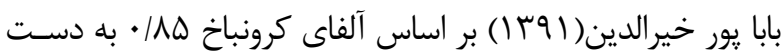
آمد. در :زوهش حاضر ضريب آلفاى كرونباخ V9/ • محاسبه شد.

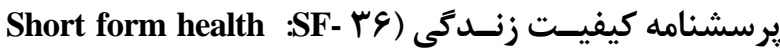

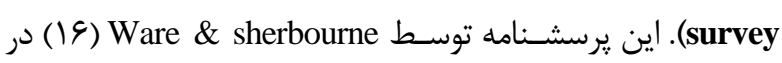

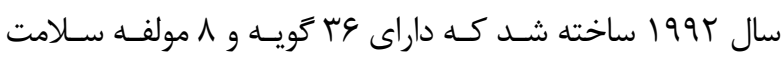
عمومى (سوالات צ

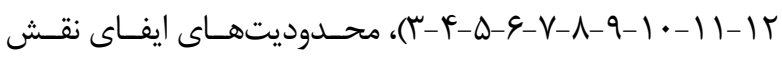

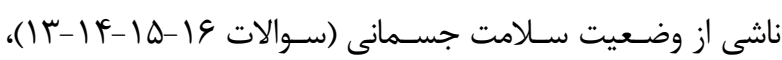
محدوديتهاى ايفاى نقش ناشـى از مشـكلات هيجـانى (سـوالات

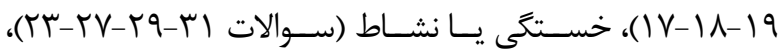

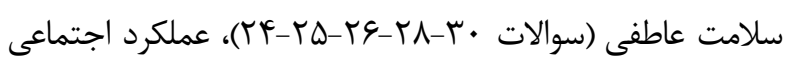

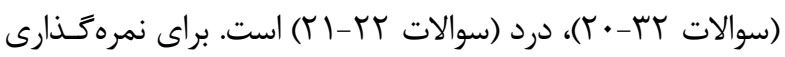

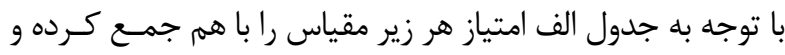

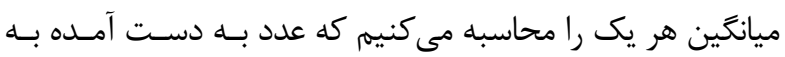

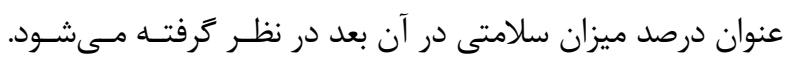

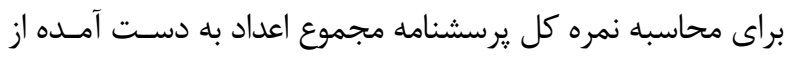

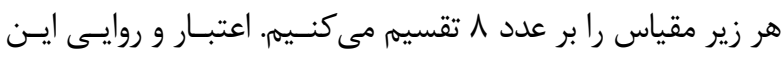

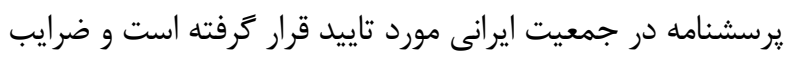

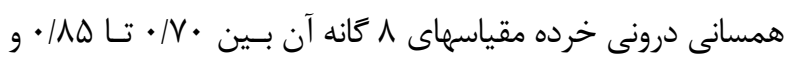

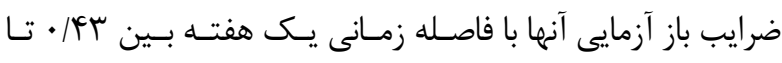

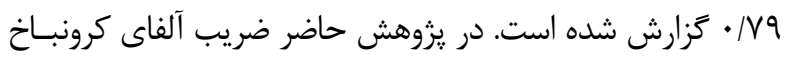

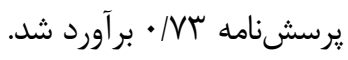

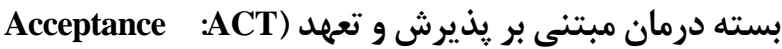

Zattle commitment therapy

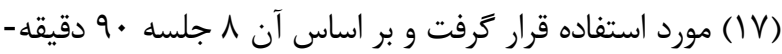

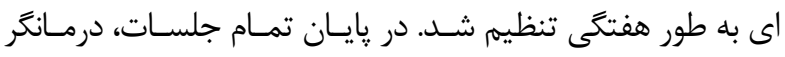

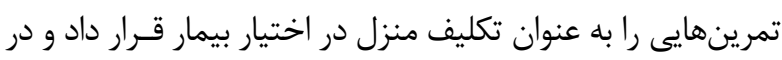

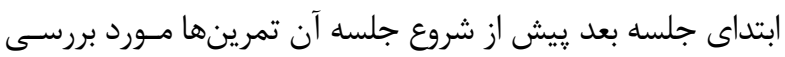

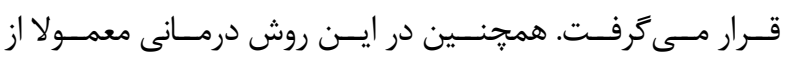

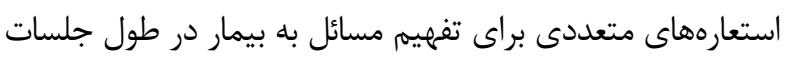

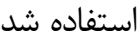
جلسه اول: يزوهشكر به معرفى درماندكى خلاق و كشف اهـداف و تلاشهاى ناموفق يرداخت و سعى داشت تا درمانجو به اين بيـنش 


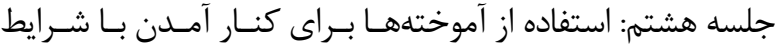

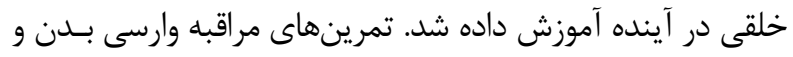

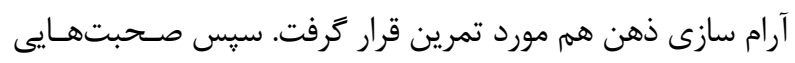

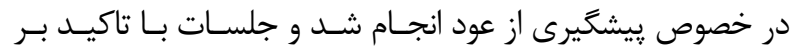
تداوم تمرينها در منزل به اتمام رسيد.

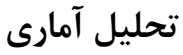

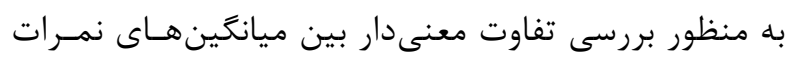

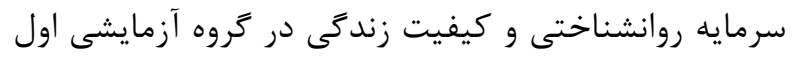
(كروهى كه درمان فراشناختى را دريافت كرده بودند)، كروه

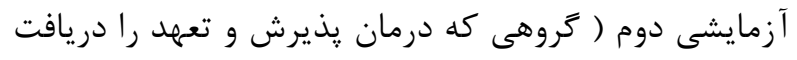

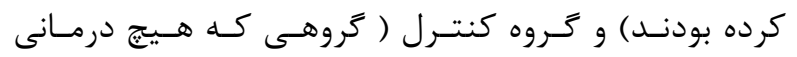

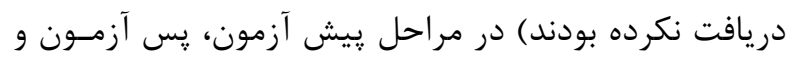

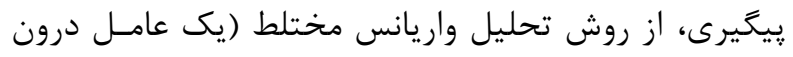

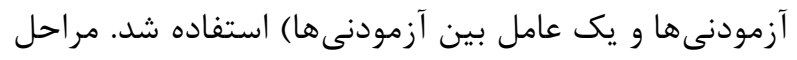

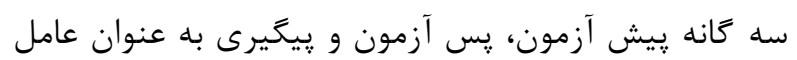

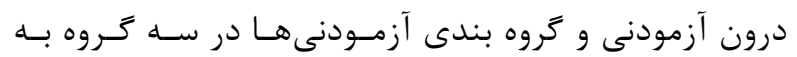

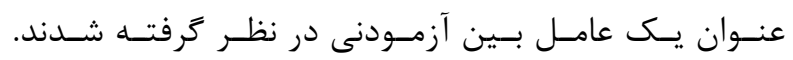

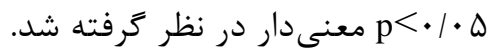

ملاحظات اخلاقى

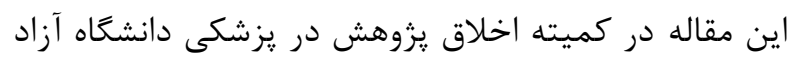

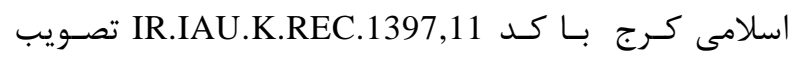
شده است.

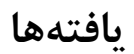

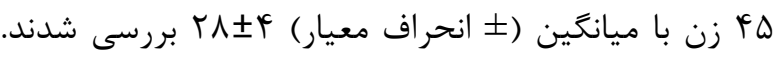

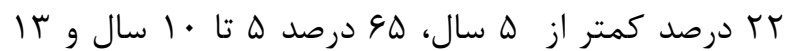

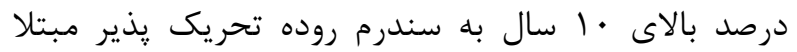

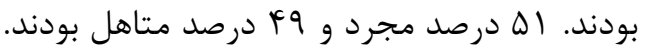

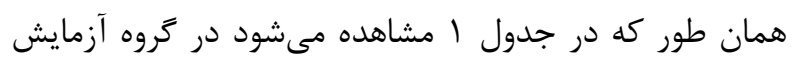
اول و دوم (درمان فراشناختى و درمان يذيرش و تعهد)

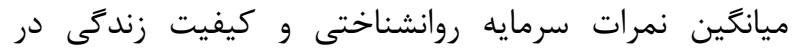

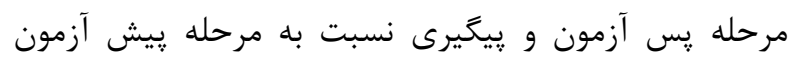

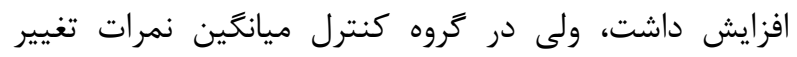

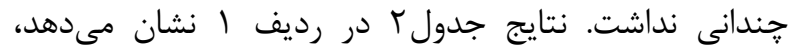

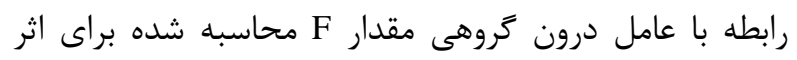

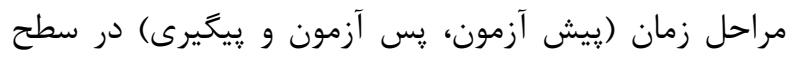

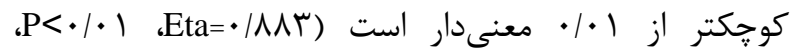
(F=r)Q/VVY

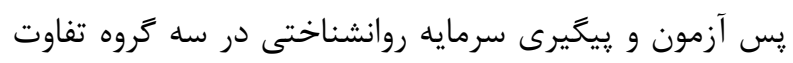

عدم مهارت اجتماعى، فقدان يشتوانه و منابع حمايتى بحـث شـد.

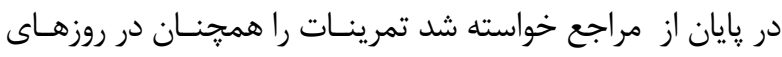
بعدى ادامه دهد.

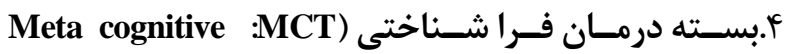

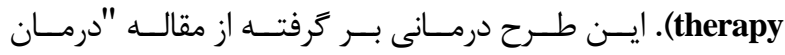
فراشناختى اضطراب و افسردكى" نوشـته Wells \& colbear (1) (1)

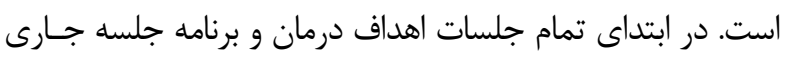

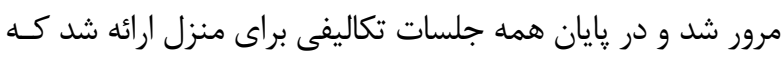

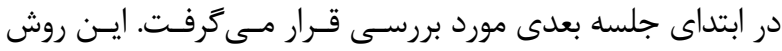

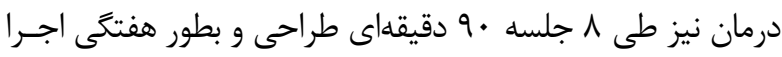
شد. جلسه اول: طى ايـن جلسـهـ فرمـول بنـدى كلـى و معرفى مــدل

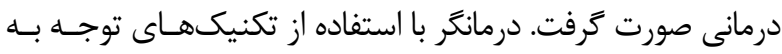

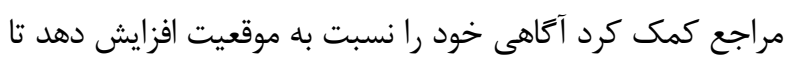
فرا شناخت افزايش يابد.

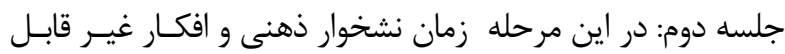

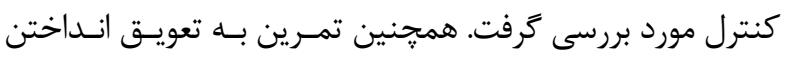

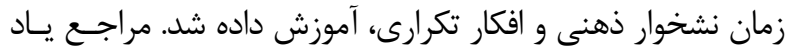
كرفت كه اين كروه از افكار قابل كنترل هستند.

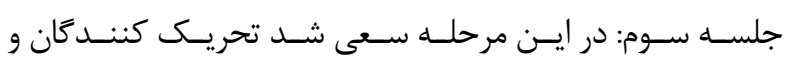

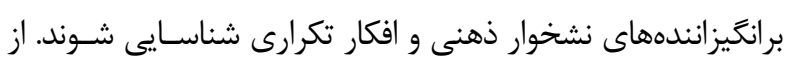

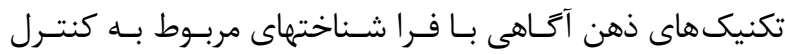
نايذيرى براى كنترل اين افكار استفاده شد.

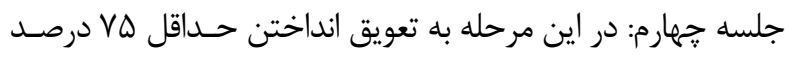

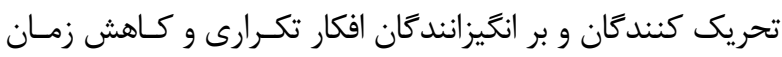

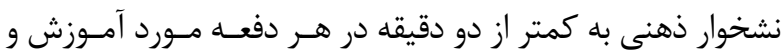
تمرين قرار ترفت.

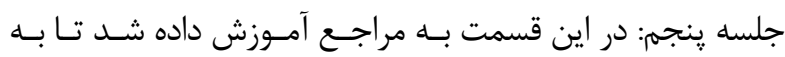

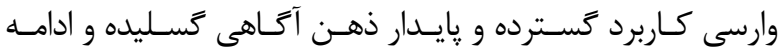
جالش با باورهاى مثبت درباره نشخوار ذهنى بيردازئ

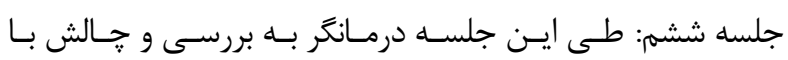

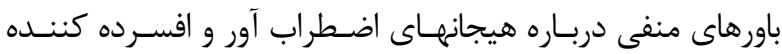

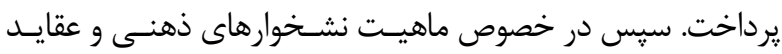

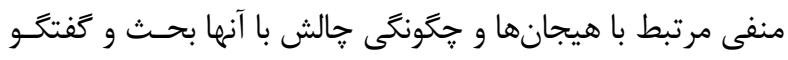

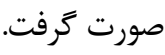
جلسه هفتم: در اين قسمت بر روى تـدوين برنامـهـهـاى جديـد و

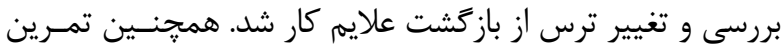

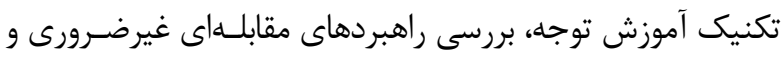

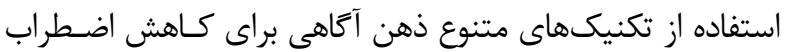
نيز مورد بررسى قرار ترفت. 


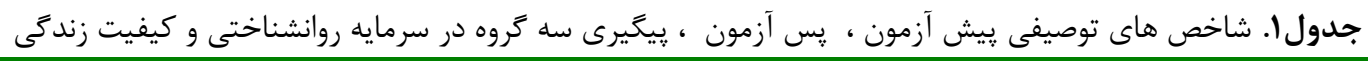

\begin{tabular}{|c|c|c|c|c|c|c|c|}
\hline \multicolumn{2}{|c|}{ يِيَيرى } & \multicolumn{2}{|c|}{ يس آزمون } & \multicolumn{2}{|c|}{ يِش آزمون } & & \\
\hline انحراف معيار & ميانگين & انحراف معيار & ميانگين & انحراف معيار & ميانگين & متغير & كروه \\
\hline $91 \cdot 9$ & $111 / 49$ & $\Delta / r \Delta$ & $111 / 48$ & $\mathrm{~V} / 9 \mathrm{~V}$ & $\Lambda 9 / r$ & سرمايه روانشناختى & 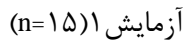 \\
\hline G|NF & $\Delta \Lambda / \uparrow \varphi$ & V/TV & $\Delta \Lambda / \cdot \Lambda$ & $\mathrm{V} / \cdot \mathrm{r}$ & $p q / r$. & كيفيت زندگى & فراشناختى \\
\hline$V / 9$. & $11 \cdot 19$ & $V / 99$ & $\| T / \cdot 9$ & $9 / 49$ & מוז & سرمايه روانشناختى & آزمايش r(n=|U( \\
\hline$\Delta / r$ & $\Delta F / \cdot 1$ & $\Delta / \& q$ & $\Delta \varphi / \Lambda \Lambda$ & V/99 & $F \wedge / T_{\Lambda}$ & كيفيت زندگى & يذيرش و تعهد \\
\hline ๑/৭१ & $\Lambda \Lambda / \Lambda$. & $\varepsilon / V \wedge$ & ^N/AG & $\mathrm{V} / \cdot$ & $\wedge 9 / \curlyvee$. & سرمايه روانشناختى & كنترل(n=|Q) \\
\hline$\Delta / 1 \Delta$ & $\boldsymbol{F} \wedge / \cdot V$ & $4 / 90$ & $F V / F \Lambda$ & $\Delta / \cdot F$ & FN/IG & كيفيت زندكى & \\
\hline
\end{tabular}

جدول r. يافته هاى مربوط به آزمون تحليل واريانس مختلط با عوامل درون گروهى و بين گروهى در سرمايه روانشناختى و كيفيت زندكى

\begin{tabular}{|c|c|c|c|c|c|c|c|}
\hline اندازه & p-value & $\mathrm{F}$ & مجذانگين & درجه آزادى & مجذورات & منابع تغيير & عوامل \\
\hline 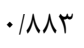 & $\cdot 1 \cdot \cdots 1$ & rIQ/VVT & $|f(\mid) / r| f$ & I/TYY & $\Delta \Lambda Y \Lambda / \Delta \vee \Lambda$ & مراحل زمان & سرمايه \\
\hline - $/ Q F q$ & $\cdot 1 \cdot \cdots 1$ & $r \Delta / \Delta q$ & $r \Delta F V / T \Delta G$ & r & $V \cdot 94 / V 11$ & كروه & روانشناختى \\
\hline$\cdot 11 \cdot$ & $\cdot 1 \cdot \cdots 1$ & $\Delta F / \cdot \Delta l$ & $\| V r / q 19$ & r/gFt & TI. r/AFF & تعامل مراحل *گروه & \\
\hline . $|F T|$ & $\cdot|\cdots|$ & $r \cdot \mid \Delta \wedge F$ & $\Delta \wedge r / \Lambda I r$ & $1 / 4 \pi$ & NFY/qq & مراحل زمان & كيفيت زندكى \\
\hline . /R & . & $V / r \& D$ & sfI/VDI & $r$ & $\mid r \Lambda r / \Delta \cdot 1$ & تروه & \\
\hline • MTS & $\cdot 1 \cdot \cdots 1$ & $1 \cdot / 1 \mathrm{~Tb}$ & $19 r / F \Delta \mu$ & r/AG. & $\Delta \Delta r / r G V$ & تعامل مراحل *گروه & \\
\hline
\end{tabular}

جدول r. خلاصه نتايج آزمون تعقيبى بونفرنى

\begin{tabular}{|c|c|c|c|c|c|}
\hline p-value & خطاى معيار & تفاوت ميانكين ها & & & مراحل/ تروه ها \\
\hline $.1 \cdot \cdot 1$ & .1999 & $-|f /| \Delta \oint_{*} *$ & سرمايه روانشناختى & ييش آزمون- يس آزمون & مراحل \\
\hline$\cdot 1 \cdot \cdots 1$ & $\cdot|9|$. & $-\Delta / \Delta G \varphi_{*} *$ & كيفيت زندگى & & \\
\hline$\cdot 1 \cdots \cdot 1$ & $\cdot \mid \Lambda \cdot r$ & $-|r / V| 1 *$ & سرمايه روانشناختى & يِش آزمون- يِيخيرى & \\
\hline$\cdot 1 \cdot \cdot 1$ & . & $-\boldsymbol{r} / q \boldsymbol{q} \cdot *$ & كيفيت زندگى & & \\
\hline$\cdot|V T|$ & $\cdot / r V r$ & - MffF & سرمايه روانشناختى & يس آزمون - پِيخيرى & \\
\hline 1 & $\cdot 19 \wedge$ & 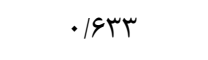 & كيفيت زندكى & & \\
\hline 1 & t/FAT & $-\cdot 1919$ & سرمايه روانشناختى & فراشناختى -يذيرش و تعهد & كروه ها \\
\hline - IATV & $1 / 98 \wedge$ & $r / \backslash \Delta \Lambda$ & كيفيت زندگى & & \\
\hline$\cdot 1 \cdot \cdot 1$ & T/FAT & $\mid Q / \cdot r r *$ & سرمايه روانشناختى & فراشناختى -كنترل & \\
\hline$\cdot / \cdot r$ & $1 / 94 \wedge$ & $V / T F V *$ & كيفيت زندگى & & \\
\hline$\cdot 1 \cdots 1$ & T/FAT & $|\Delta / V| \mid *$ & سرمايه روانشناختى & يذيرش و تعهد - كنترل & \\
\hline . & $1 / 991$ & $\Delta / 1 \wedge ৭ *$ & كيفيت زندگى & & \\
\hline
\end{tabular}

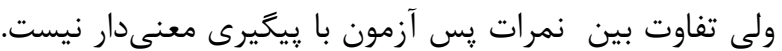
مقايسه ميانگينهاى تعديل شده نشان مىدهد كه نمرات بـ لين

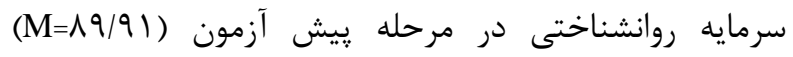

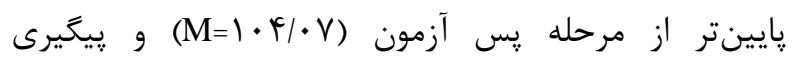

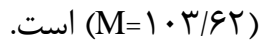

همجنين بين اثر گروههاى آزمايشى درمان فراشناخت و درمان تعهد و يذيرش با گروه كنترل تفاوت معنى دارى وجود داشت. مقايسه ميانگينهاى تعديل شده نشان مىدهد كه نمرات
معنى دارى وجود داشت. همجنين براى عامل بين گروهى

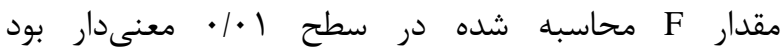
(Eta=•/DFq) كلى سرمايه روانشناختى در سه گروه آزمايش و كنترل تفاوت معنى دارى وجود داشت. نتايج آزمون تعقيبى بونفرنى به منظور بررسى تفاوت بين ميانگين ها محاسبه شد. نتايج جدول

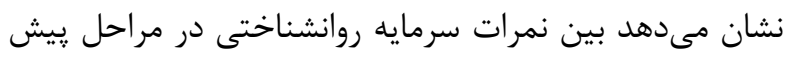
آزمون با پس آزمون و ييگيرى تفاوت معنى مارى وجود دارد، 
مراحل و گروه مقدار F محاسبه شده براى اثر مراحل ( ييش

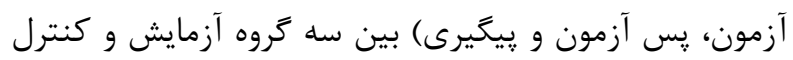

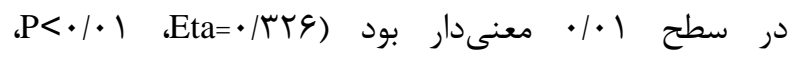

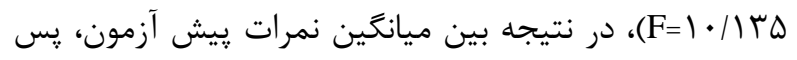

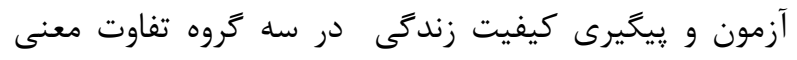

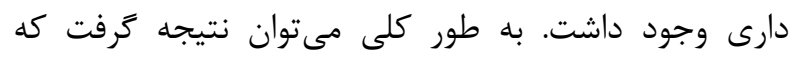

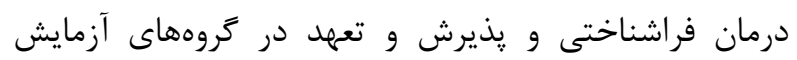

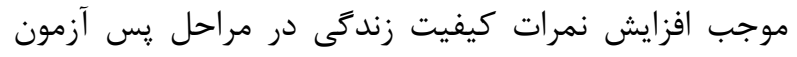

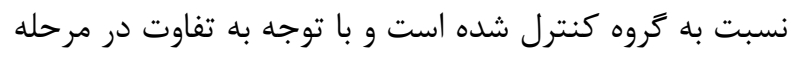

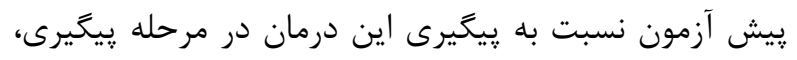

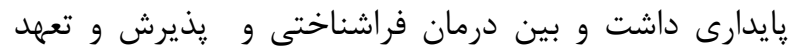
تفاوت معنى دارى وجود نداشت.

بحث

طبق يافتههاى يزوهش هر دو روش درمانى به يك اندازه

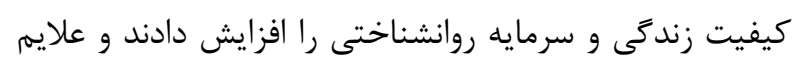
سندرم روده تحريك يذير نيز طبق نظر يزشك معالج و خود بيماران كاهش يافت. اين نتايج همسو با يافتههاى سورديا،

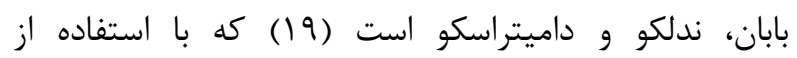

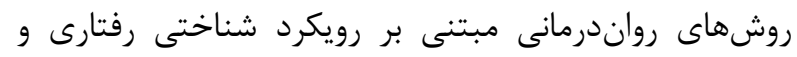

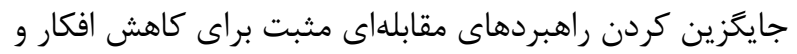

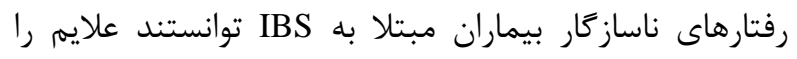

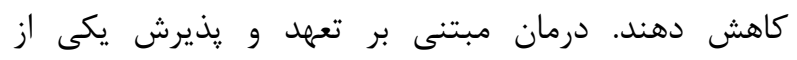
شاخههاى درمان رفتارى شناختى است كه در مطالعه حاضر داض دران اثر بخشى خود را نشان داد. در مطالعه ديخرى كه از داز درمان

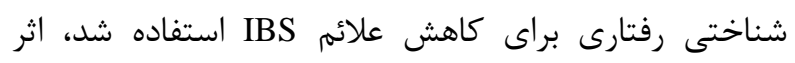

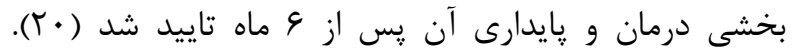

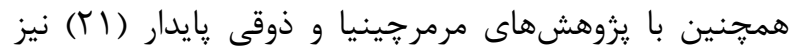

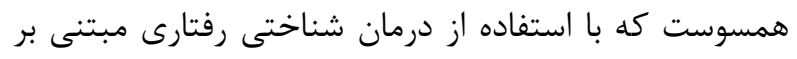

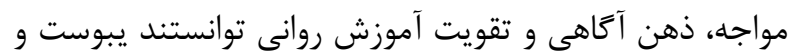

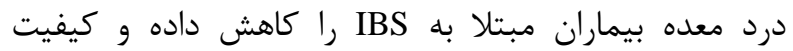

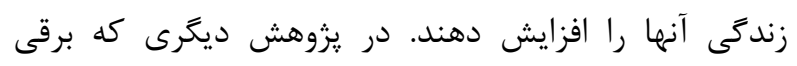

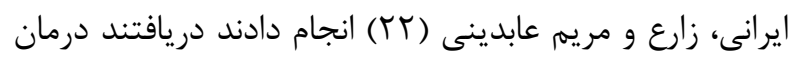

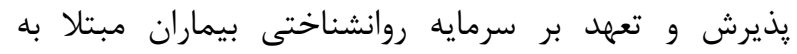

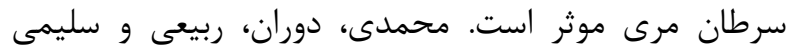

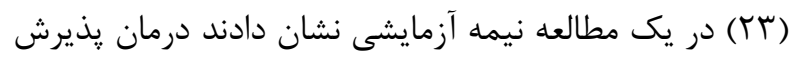

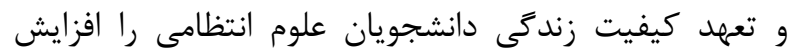
مىدهد. بررسى نتايج يزوهش حاضر نشان داد بين درمان

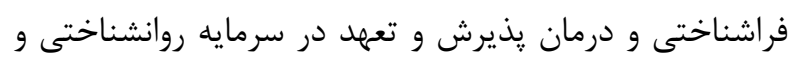

سرمايه روانشناختى در گروه آزمايشى با درمان فراشناختى

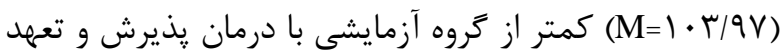

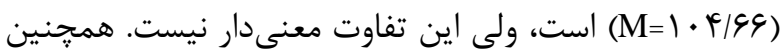
در رابطه با تعامل عوامل مراحل و گروه مقدار F محاسبه شده

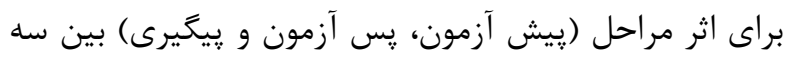

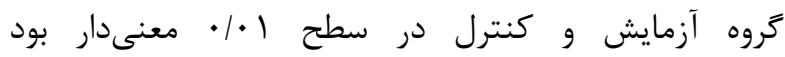

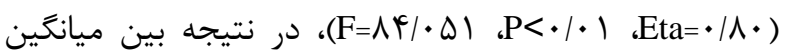

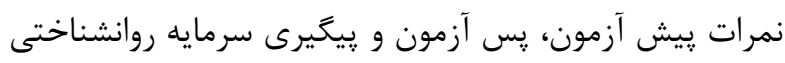

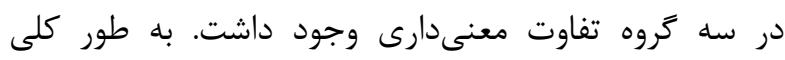

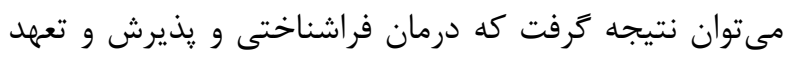

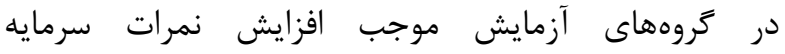

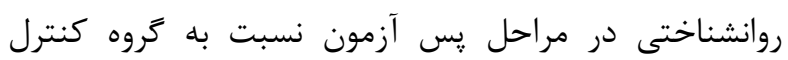

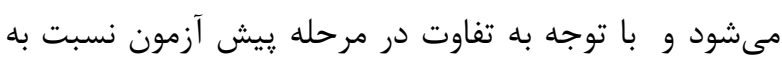

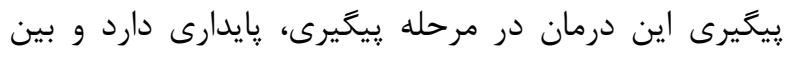

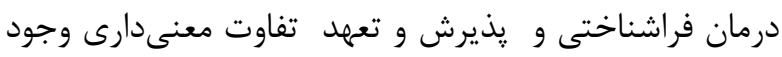

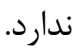
نتايج جدول r در رديف \& نشان مىدهد، رابطه با عامل درون كروهى مقدار F محاسبه شده براى اثر مراحل زمان (ييش

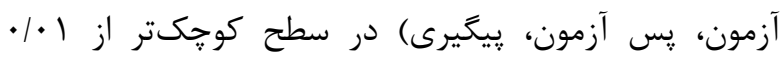

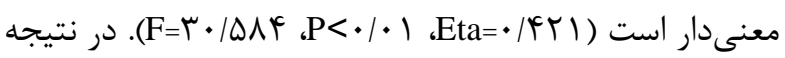

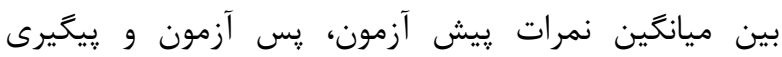

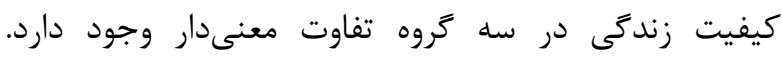

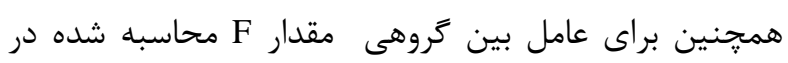

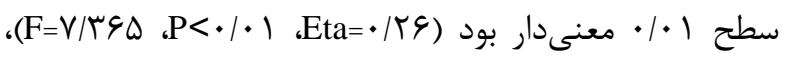

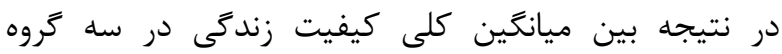

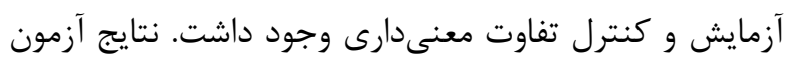

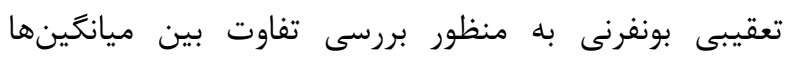

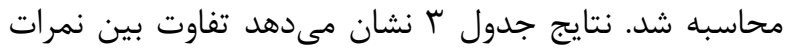

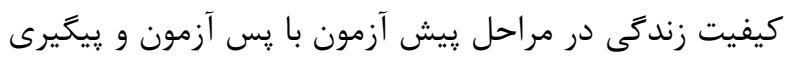

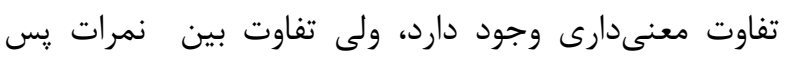

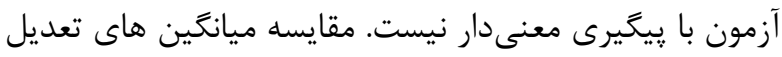

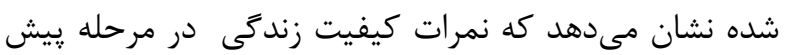

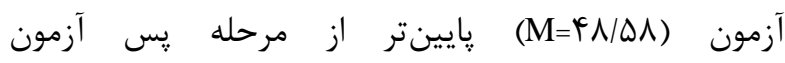

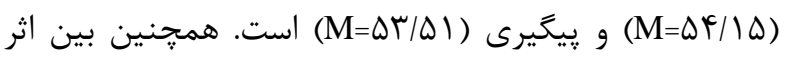
كروههاى آزمايشى درمان فراشناخت و درمان تعهد و ويذيرش

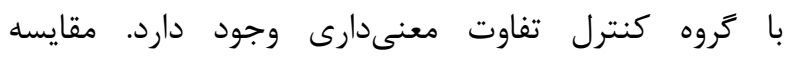

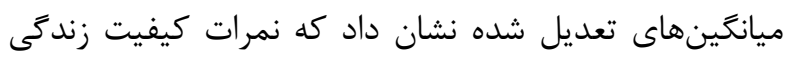

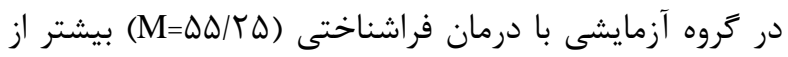

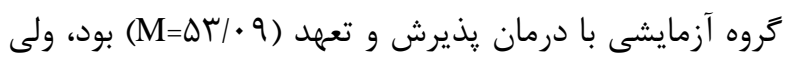

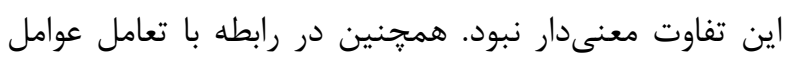


افسردگى و نشخوار ذهنى موثرند، البته آنها نيز تفاوت معنى دارى در اثر بخشى هريك از روشها بر روى بيماران به دست

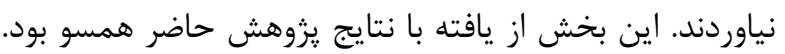

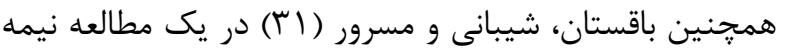
آزمايشى مبتنى بر درمان يذيرش و تعهد بر ادراك بيمارى و

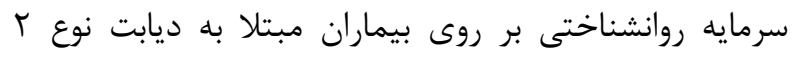

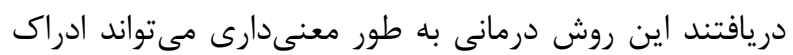
بيمارى و عوامل سرمايه روانشناختى اين گروه از بيمارىها راسئ

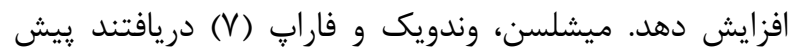
بينى كنندههاى كيفيت زندگى يايين در افراد مبتلا به سندرم روده تحريك يذير شامل بيماريهاى عضوى و شكايات مربوط به بهداشت روانى هستند. اين نتايج نيز در راستاى يافتههاى يزوهش حاضر بود. در كل، نتايج اين يزوهش اثر بخشى رواندرومانى هاى مبتنى بر يذيرش و تعهد و فراشناختى در افزايش سرمايه روانشناختى و

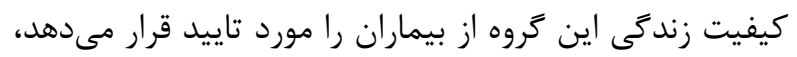

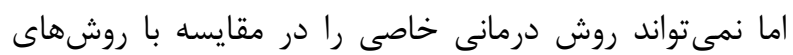
ديخر براى كاهش علايم بيمارى و افزايش متغيرهاى وابسته فوق ييشنهاد كند. لذا در يزوهشهاى آتى ييشنهاد مى شىود در يك شرايط آزمايشى كنترل شده به مقايسه روشهاى بئ رواندرمانى موثر بر سندرم روده تحريك يذير در گروههاى

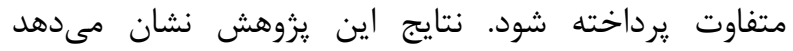

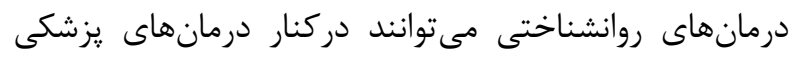

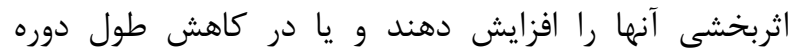
درمانهاى دارويى موثر باشند. همجنين لازم به ذكر است كه با توجه به محدوديتهاى موجود نتايج اين مطالعه تنها در محدوده جامعه خود قابل تعميم است. بو موديه

\section{تشكر و قدردانى}

در پايان از كليه شركت كنند اجراى اين يزوهش يارى رساندند، نهايت قدردانى و تشكر را

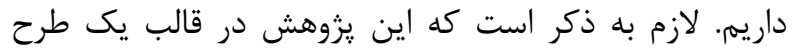

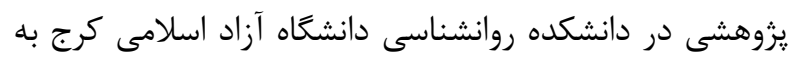

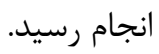

كيفيت زندگى تفاوتى وجود ندارد. اگرجه مرور مطالعات

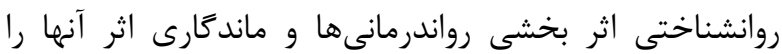

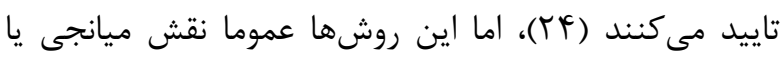
تعديل كننده را در درمان سندرم روده تحريك يذير بر عهده دارند. بعضى از مطالعات نيز يايدارى درمان شناختى رفتارى را ران تاييد نكرده و به جاى آن درمانهاى جايگزين مانند درمان يذيرش و تعهد و ذهن آتاهى را در كاهش اين علائم ريشنهاد مى كنند كه داراى ماندگارى اثر نيز است (ه) (ه). كينسينگر (Y) نيز طى يزوهشى درمان شناختى رفتارى و رويكردهاى

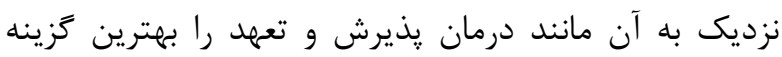
براى بهبودى سندرم روده تحريك يذير مىداند. تالونن، زميك

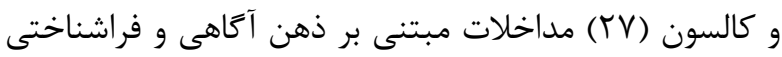
را براى كاهش علائم بيماريهاى سرطان، سندرم روده تحريك يذير، صرع، درد مزمن، وزوز گوش و مشكلات قلبى رات را در

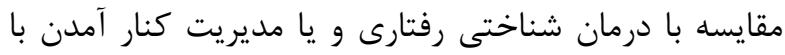

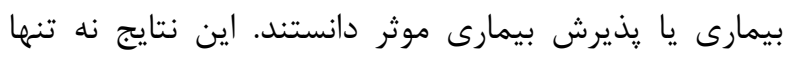

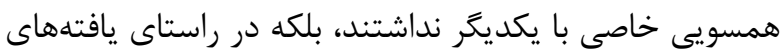
يزوهش حاضر كه تفاوت معنىدارى بين درمان يذيرش و تعهد و فراشناخت نيافت، نيز نبودند. در تبيين آن مىتوان به به بهني

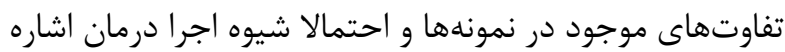
كرد كه در يثزوش حاضر بصورت انفرادى برگزار شد. همجنين تفاوت در سطح هيجانى و خواستخاههاى بيماران نيز از اهميت بسيارى برخوردار است. از طرف ديخر، نمونههاى يزوهش حاضر به بيمارى ديخرى غير از نشانگان روده تحريك يذير دجار نبودند. مطالعه ديخرى نيز اثر بخشى مداخلات روان

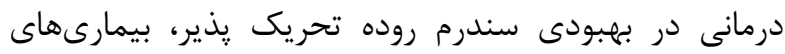

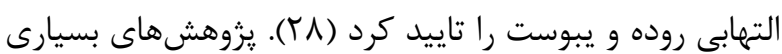
اثر بخشى درمانهاى فراشناختى و يذيرش و تعهد بر بيماران

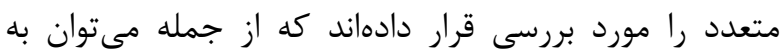
يزوهش ادبول-كارلمن، الجوتسن، لينتون، بورسما، شروتن و ريسيبر (Yq) اشاره كرد كه اثر بخشى درمان شناختى رفتارى آنو و يذيرش و تعهد بر كاهش مشكلات معدى رودهاى را آزمودند و دريافتند اين روشها علايم روانيزشكى را در اين بيماران

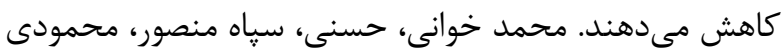

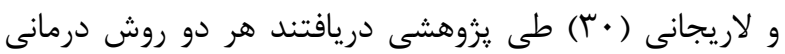
شناختى مبتنى بر حضور ذهن و درمان فرا شناختى بر علايم

\section{REFERENCES}

1. Sugawara N, Sato K, Takahashi I, Satake R, Fukuda S, Nakaji S, et al. Depressive symptoms and coping behaviors among individuals with irritable bowel syndrome in Japan. Intern Med 2017;56:493-8.

2. Towsyfyan N. The effectiveness of acceptance and commitment therapy on the improving of resilience and optimism in adolescents with major depressive disorder. Int J Human 2017;7:239-54. 
3. Owyang CH. Irritable bowel syndrome. In: Longo DL, Fauci, AS, Kasper DL, Hauser SL, Jameson JL, Loscalzo J, editors. Harrison's principles of internal medicine. 18th ed. Philadelphia: McGraw- Hill; 2012. P.2496-501.

4. Almquist E, Törnblom H, Simrén M. Practical management of irritable bowel syndrome: a clinical review. Minerva Gastroenterol Dietol 2016;62:30-48.

5. Eskafi SZ, Varasteh AR. Life satisfaction, anxiety and depression in the irritable bowel syndrome. J Guilan Univ Med Sci 2016;26:8-19. [In Persian]

6. Michalsen VL, Vandvik PO, Farup PG. Predictors of health-related quality of life in patients with irritable bowel syndrome. A crosssectional study in Norway. Health Qual Life Outcomes 2015;13:113.

7. Porcelli P, De Carne M, Leandro G. The role of alexithymia and gastrointestinal-specific anxiety as predictors of treatment outcome in irritable bowel syndrome Leandro. Compr Psychiatry 2017;73:127-35.

8. Sibelli A, Chalder T, Everitt H, Workman P, Bishop FL, Moss-Morris R. The role of high expectations of self and social desirability in emotional processing in individuals with irritable bowel syndrome: A qualitative study. Br J Health Psychol 2017;22:737-62.

9. Eriksson EM, Andrén KI, Kurlberg GK, Eriksson HT. Aspects of the non-pharmacological treatment of irritable bowel syndrome. World J Gastroenterol 2015;21:11439-49.

10. Ferreira NB, Eugenicos MM, Paul G, Gillanders D. Using acceptance and commitment therapy in irritable bowel syndrome. Qual Life Res 2013;22:1761-6.

11. Ferreira NB, Gillanders D, Paul G, Morris ME. Pilot study of acceptance and commitment therapy for irritable bowel syndrome: A preliminary analysis of treatment outcomes and processes of change. Clinical Psychologist 2018;22:241-50.

12. Laird KT, Tanner-Smith EE, Russell AC, Hollon SD, Walker LS. Comparative efficacy of psychological therapies for improving mental health and daily functioning in irritable bowel syndrome: a systematic review and meta- analysis. Clin Psychol Rev 2017;51:142-52.

13. Shahi Bahadori KH, Habibi Klibar J. Effectiveness of group reality therapy on psychological capital. Self-esteem and social well-being of the elderly. J Aging Psychol 2016;2:153-65.

14. Luthans F, Luthans K, Luthans BC. Positive psychological capital: beyond human and social capital. Bus Horiz 2014;47:45-50.

15. Luthans F, Avolio BJ. Positive psychological capital: measurement and relationship with performance and satisfaction. Pers Psychol 2007;6:138-46.

16. Ware JE, Sherboune CD. The MOS 36-item short form health survey (SF-36). Med Care 1992;30:473-83.

17. Zettle RD. Acceptance and commitment therapy VS. Systematic desensitization in treatment of mathematics anxiety. Psychol Rec 2003;53:197-215.

18. Walls A, Colbear JS. Treating posttraumatic stress disorder with metacognitive therapy. J Clin Psychol 2012;68:373-81.

19. Surdea-Blaga T, Baban A, Nedelcu L, Dumitrascu DL. Psychological interventions for irritable bowel syndrome. J Gastrointestin Liver Dis 2016;25:359-66.

20. Klem F, Wadhwa A, Prokop LJ, Sundt WJ, Farrugia G, Camilleri M, et al. Prevalence, risk factors, and outcomes of irritable bowel syndrome after infectious enteritis: a systematic review and meta-analysis. Gastroenterology 2017;152:1042-54.

21. Marmarchi Nia M, Zoghi Paydar MR. The effectiveness of acceptance and commitment therapy on hope and happiness of adolescent girls under coverage of welfare. AJAP 2017;11:157-74.

22. Barghi Irani Z, Zare H, Abedini M. The Effectiveness of acceptance and commitment (ACT) therapy on the psychological capital of patients with esophageal cancer. J Health Psychol 2016;14:5-19.

23.Mohammadi R, Doran B, Rabiee M, Salimi SH. The effectiveness of treatment based on admission and commitment to the quality of life of students at a military center. Quarterly Journal of Police Medicine 2017;6:21-30.

24. Radziwon CD, Lackner J. Cognitive behavioral therapy for ibs: how useful, how often, and how does it work? Curr Gastroenterol Rep 2017;19:49.

25. Kinsinger SW. Cognitive-behavioral therapy for patients with irritable bowel syndrome: current insights. Psychol Res Behav Manag 2017;19:231-7. 
26. Toivonen KI, Zernicke K, Carlson LE. Web-based mindfulness interventions for people with physical health conditions: systematic review. J Med Internet Res 2017;19:e303.

27.Ballou S, Keefer L. Psychological interventions for irritable bowel syndrome and inflammatory bowel diseases. Clin Transl Gastroenterol 2017;8:214.

28. Edebol-Carlman H, Ljotsson B, Linton SJ, Boersma K, Schrooten M, Repsilber D, et al. Face- to- face cognitivebehavioral therapy for irritable bowel syndrome: the effects on gastrointestinal and psychiatric symptoms. Gastroenterol Res Pract 2017;2017:8915872.

29. Mohammad Khani P, Hasani F, Sepah Mansur M, Mahmoodi G, Lahijani Z. Comparison of the effectiveness of cognitive therapy based on the presence of mind and metacognitive therapy on rumination and depression symptoms. Psychol Res 2014;6:101-18.

30. Baghestan A, Baghban Sheibani Aerab Kh, Javedani Masrur M. Acceptance and commitment based therapy on disease perception and psychological capital in patients with type II diabetes. Horizon of Medical Sciences 2017;23:135-40.

31. Michalsen VL, Vandvik PO, Farup PG. Predictors of health-related quality of life in patients with irritable bowel syndrome. A cross sectional study in Norway. Health Qual Life Outcomes 2015;13:113. 